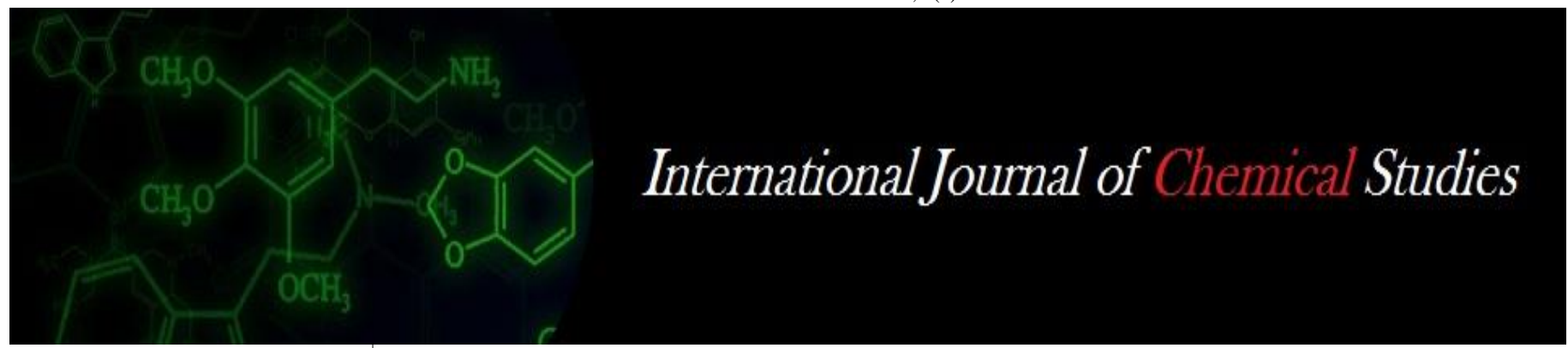

P-ISSN: 2349-8528

E-ISSN: 2321-4902

www.chemijournal.com

IJCS 2020; 8(4): 3131-3132

(C) 2020 IJCS

Received: 28-05-2020

Accepted: 30-06-2020

\section{A Poorani}

Assistant Professor, Veterinary

College and Research Institute,

Namakkal, Tamil Nadu, India

B Suresh Subramonian

Professor, Madras Veterinary

College, Chennai, Tamil Nadu,

India

\section{A Elange}

Professor, Veterinary College and Research Institute, Namakkal,

Tamil Nadu, India

\section{G Kumaresan}

Professor, Veterinary College and

Research Institute, Namakkal,

Tamil Nadu, India
Corresponding Author:

\section{A Poorani}

Assistant Professor, Veterinary

College and Research Institute,

Namakkal, Tamil Nadu, India

\section{Impact on microbial viability of soy enriched probiotic shrikhand stored at $4{ }^{\circ} \mathrm{C}$}

\author{
A Poorani, B Suresh Subramonian, A Elango and G Kumaresan
}

DOI: https://doi.org/10.22271/chemi.2020.v8.i4al.10133

\begin{abstract}
The impact on microbial viability of soy enriched probiotic shrikhand stored at $4{ }^{\circ} \mathrm{C}$ was studied. Standard plate count, Yeast and mould count, Bifidobacterial count were analyzed on 0 day, 3rd day and $7^{\text {th }}$ day respectively. There was no significant difference within days in total plate count between the control, Shrikhand prepared from synbiotic milk by substitution of enzymatically modified soymilk to bifidogenic milk at 10 per cent level and 1.5 per cent starter culture (SSyM10), Shrikhand prepared from synbiotic milk by substitution of enzymatically modified soymilk to bifidogenic milk at 15 per cent level and 1.5 per cent starter culture $\left(\mathrm{SSyM}_{15}\right)$ and Shrikhand prepared from synbiotic milk by substitution of enzymatically modified soymilk to bifidogenic milk at 20 per cent level and 1.5 per cent starter culture $\left(\mathrm{SSyM}_{20}\right)$ at 0,3 and 7 days intervals. The yeast and mould were found to be absent in control, $\mathrm{SSyM}_{10}$, $\mathrm{SSyM}_{15}$ and $\mathrm{SSyM}_{20}$ at 0 and 3 days interval. Yeast and mould count at 7 days interval for control, $\mathrm{SSyM}_{10}, \mathrm{SSyM}_{15}$ and $\mathrm{SSyM}_{20}$ were $1.12,1.30,1.44$ and 1.61 respectively. There was no significant difference in yeast and mould count between at different intervals. The number of Bifidobacterium longum counts in selective media for control, $\mathrm{SSyM}_{10}, \mathrm{SSyM}_{15}$ and $\mathrm{SSyM}_{20}$ at 0,3 and 7 days intervals revealed no significant difference at $(P<0.05)$ between the different levels.
\end{abstract}

Keywords: Soy enriched probitic Shrikhand, standard plate count, yeast and mould count, Bifidobacterium longum count

\section{Introduction}

Shrikhand is a famous traditional fermented and sweetened milk product of Indian origin. Shrikand with its distinct taste, richness, delicacy, diversity has good market value. Shrikhand is a semi-soft, sweetish-sour milk product prepared from lactic fermented curd (Singh et al., 2014) ${ }^{[2]}$ The name shrikhand is derived name from the Sanskrit word "Shikharani" meaning a curd prepared with added sugar, flavouring agents like saffron, fruits and nuts. It is popular in western India and is very refreshing particularly during summer months and is recommended for people with as it have (Swapna and Chavannavar, 2013) ${ }^{[3]}$.

\section{Material and Methods}

Soy milk was prepared with the help of soy flour.It was treated with proteolytic enzyme, Neutrase for the preparation of Enzymatically Modified Soy Milk and subsequent addition to synbiotic milk (SyM) at 10, 15, 20 per cent levels. Bifidobacterium longum culture was activated by propagation in reconstituted sterile skim milk. Enzymatically modified synbiotic soy milk was treated with $1.5 \%$ starter culture and incubated at $37{ }^{\circ} \mathrm{C}$ for about 10 hours to reach acidity of $1 \%$.( Boghra et al, 2000) ${ }^{[1]}$.

The whey was drained and chakka that was collected was kneaded with sugar and cardamom to make delicious soy enriched enzymatically modified probiotic shrikhand. The microbial viability of soy enriched probiotic shrikhand stored at $4{ }^{\circ} \mathrm{C}$ was studied.

Suitable dilutions were selected based on preliminary trials. Phosphate buffer solution used for serial dilution was prepared as described in BIS (IS: 5401 - 1969) ${ }^{[9]}$.

The Standard Plate count and Yeast and mould count counts were determined using the procdure described in BIS Handbook, BIS Part XI: 1981), IS:5401 (1969) ${ }^{[9]}$ respectively. 
Results

Table 1: Microbial quality of soy enriched probiotic shrikhand stored at $4{ }^{\circ} \mathrm{C}(\log 10 \mathrm{cfu} / \mathrm{g})$

\begin{tabular}{|c|c|c|c|c|c|}
\hline Days & Type of Count & Control & SSyM $_{10}$ & SSyM $_{15}$ & SSyM $_{20}$ \\
\hline \multirow{3}{*}{0 day } & Standard plate Count & $7.79 \pm 0.48$ & $7.91 \pm 0.34$ & $8.21 \pm 0.83$ & $8.14 \pm 0.42$ \\
\cline { 2 - 6 } & Yeast and mould & 0 & 0 & 0 & 0 \\
\cline { 2 - 6 } & Bifidobacterium longum & $7.82 \pm 0.64$ & $7.81 \pm 0.13$ & $8.32 \pm 0.17$ & $8.15 \pm 0.39$ \\
\hline \multirow{3}{*}{$3^{\text {rd }}$ day } & Standard plate Count & $8.63 \pm 0.28$ & $8.59 \pm 0.32$ & $8.48 \pm 0.22$ & $8.65 \pm 0.23$ \\
\cline { 2 - 6 } & Yeast and mould & 0 & 0 & 0 & 0 \\
\hline \multirow{3}{*}{$7^{\text {th }}$ day } & Bifidobacterium longum & $6.05 \pm 0.21$ & $6.14 \pm 0.24$ & $6.15 \pm 0.11$ & $6.26 \pm 0.28$ \\
\cline { 2 - 7 } & Standard plate Count & $7.89 \pm 0.34$ & $8.17 \pm 0.29$ & $8.21 \pm 0.19$ & $7.95 \pm 0.19$ \\
\cline { 2 - 7 } & Yeast and mould & $1.12 \pm 0.43$ & $1.30 \pm 0.20$ & $1.44 \pm 0.03$ & $1.61 \pm 0.05$ \\
\cline { 2 - 7 } & Bifidobacterium longum & $5.54 \pm 0.16$ & $5.52 \pm 0.14$ & $5.33 \pm 0.15$ & $5.27 \pm 0.33$ \\
\hline
\end{tabular}

\# Percentages (Mean \pm SE). Average of six trials. Mean values bearing different superscripts in a column differ significantly $* *(P<0.01)$

\begin{tabular}{|l|c|}
\hline Control & Shrikhand from Synbiotic milk, 1.5\% starter culture \\
\hline SSyM $_{10}$ & $\begin{array}{c}\text { Shrikhand prepared from Synbiotic Milk by substitution of enzymatically modified soymilk to bifidogenic milk at 10 per cent level,1.5 } \\
\text { per cent starter culture }\end{array}$ \\
\hline SSyM $_{15}$ & $\begin{array}{c}\text { Shrikhand prepared from Synbiotic Milk by substitution of enzymatically modified soymilk to bifidogenic milk at 15per cent level, 1.5 } \\
\text { per cent starter culture }\end{array}$ \\
\hline SSyM $_{20}$ & $\begin{array}{c}\text { Shrikhand prepared from Synbiotic Milk by substitution of enzymatically modified soymilk to bifidogenic milk at 20 per cent level, } \\
1.5 \text { per cent starter culture }\end{array}$ \\
\hline
\end{tabular}

\section{Discussion}

Table 1 above represents the microbial quality of soy enriched probiotic shrikhand stored at $4{ }^{\circ} \mathrm{C}$. There is no significant difference $(P>0.05)$ in Bifidobacterial count, total count and yeast count between control, $\mathrm{SSyM}_{10}, \mathrm{SSyM}_{15}$ and $\mathrm{SSyM}_{20}$ at 0,3 and 7 days interval.

The yeast and mould were found to be absent in control, $\mathrm{SSyM}_{10}, \mathrm{SSyM}_{15}$ and $\mathrm{SSyM}_{20}$ at 0 and 3 days interval. Yeast and mould count at 7 days interval for control, $\mathrm{SSyM}_{10}$, $\mathrm{SSyM}_{15}$ and $\mathrm{SSyM}_{20}$ were $1.12,1.30,1.44$ and 1.61 respectively $[4,5,6]$. There was no significant difference in yeast and mould count between at different intervals. The number of Bifidobacterium longum counts in selective media for control, $\mathrm{SSyM}_{10}, \mathrm{SSyM}_{15}$ and $\mathrm{SSyM}_{20}$ at 0,3 and 7 days intervals revealed no significant difference at $(P<0.05)$ between the different levels.

The number of bacterial count expressed in $\log _{10} \mathrm{cfu} / \mathrm{gm}$ increased slightly with increasing level of enzymatically modified soymilk to bifidogenic milk but there was no significant difference. This indicated that lactic acid bacteria are able to survive at low temperature as reported by Okereke [1].

Yeast and mould as well coliforms count were found nil at the $0^{\text {th }}$ day and after 5 days. However, no significant difference were observed on bifidobacterial count on all the day ${ }^{[7]}$.

Bifidobacterial count got decreased as well as total count also got decreased in the stored samples which were stored for 7 days and there was no significant difference of the yeast and mould count was noticed on $7^{\text {th }}$ day indicates spoilage.

Considering microbial evaluation, the $\mathrm{SSyM}_{15}$ sample was judged as the best product with good consistency and acceptability.

\section{References}

1. Okereke A, Montville TJ. Bacteriocin-mediated inhibition of Clostridium botulinum spores by lactic acid bacteria at refrigeration and abuse temperatures. Applied and Environmental Microbiology. 1991; 57(12):34233428.

2. Singh D, Singh J, Kumar S, Verma T. Microbiological Evaluation of Soy Fortified Shrikhand by using Response
Surface Methodology. International Journal of Applied Biology and Pharmaceutical Technology. 2014; 5(1):1-7.

3. Swapna G, Chavannavar SV. Shrikhand: Value added traditional dairy product. International Journal of Food and Nutritional Sciences. 2013; 2(4):45-51.

4. Atherton HV, Newlander JA. Chemistry and testing of dairy products, AVI publishing company, West poot, Connecticut, Inc. USA, 1977, 4

5. FSSA. The Food Safety and Standards Act, chapter 2Food Product Standards chakka and Shrikhand, Commercial Law Publishers (India) Pvt. Ltd, 2011, 204

6. ISI Handbook of Food Analysis. 1981. SP: 18 (Part XI Dairy Products).Bureau of Indian Standards, Manak Bhavan, Bahadur Shah Zafar Marg, New Delhi, India, 1981, 11-18.

7. IS: 1479.1960. Method of Test for Dairy Industry. Rapid Examination of milk. Indian standards Institution, New Delhi. 1479, 29

8. IS: 5401. 1969. Methods for detection and estimation of coliform bacteria in food stuffs. Indian Standards Institution, New Delhi, 1969, 2-9.

9. IS: 9532. 1980. Specifications for chakka and Shrikhand, Indian standards Institution, New Delhi, 1980, 5-7.

10. IS: 5402. 2002/ ISO: 4833. 1991. Microbiology- General guidance for the enumeration of micro-organisms, 2002. 